\title{
Diagnostic fingerprints ISSR/SSR for tropical leguminous species Stylosanthes capitata
}

\section{and Stylosanthes macrocephala}

\author{
Ana Lilia Alzate-Marin ${ }^{\star \star} \odot$, Carolina Costa-Silva1 ${ }^{\circledR}$, Priscila Marlys Sá Rivas ${ }^{1 \oplus}$, Fernando Bonifacio-Anacleto ${ }^{1}$, Leticia Gobett Santos ${ }^{2}$,

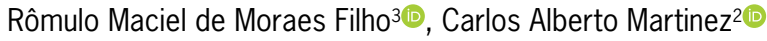

1Universidade de São Paulo/FMRP - Lab. de Genética Vegetal - Depto. de Genética, Av. Bandeirantes, 3900 14049-900 - Ribeirão Preto, SP - Brasil.

2Universidade de São Paulo/FFCLRP - Depto. de Biologia Lab. de Fisiologia Vegetal.

3Universidade Federal Rural de Pernambuco - Depto. de Agronomia, R. Dom Manuel de Medeiros, s/n - 52171-900 Recife, PE - Brasil.

*Corresponding author <anaalzate@fmrp.usp.br>

Edited by: Gerson Barreto Mourão

Received July 30, 2018

Accepted October 30, 2018
ABSTRACT: Stylosanthes capitata Vogel and Stylosanthes macrocephala M.B.Ferreira \& Sousa Costa are two forage leguminous species of agronomic importance for animal husbandry in tropical environments. The physical mixture of both species (80\% S. capitata and $20 \%$ S. macrocephala) comprises the commercial cultivar "Estilosantes Campo Grande". However, proximity of fields for seed production may contaminate seed lots, compromising seeds quality. The combined use of dominant and co-dominant molecular markers is an appropriate strategy to certificate genetic purity and perform diversity studies of cultivars. In this research, a set of ISSR (Inter-Simple Sequence Repeat polymorphic DNA) and SSR (Simple Sequence Repeat polymorphic DNA) molecular markers were standardized to characterize $S$. capitata and S. macrocephala species and evaluate the genetic purity of commercial samples. Four ISSR markers (UBC 2, 864, 885, 886) and SSR marker SC18-01 G4B showed precise species-specific electrophoretic fingerprints for both species. Electrophoretic patterns of ISSR molecular markers should be displayed first to confirm the sample identification. The structure analysis showed that the less contaminated sample was S. capitata with $97 \%$ of its genetic composition assigned to a single genetic cluster vs. $95 \%$ for S. macrocephala. S. capitata has greater genetic diversity $\left(\operatorname{ISSR}_{\mathrm{He}}: 0.292 ; \mathrm{SSR}_{\mathrm{He}}: 0.57\right)$ than S. macrocephala (ISSR $\left.{ }_{\mathrm{He}}: 0.285 ; \mathrm{SSR}_{\mathrm{He}}: 0.16\right)$; however, this difference was only significant with SSR molecular markers. As these genetic resources have considerable ecological, agronomic and economic importance, tools for accurate species identification and genetic studies are essential for further seed multiplication, as well as for improvement and conservation of cultivars.

Keywords: genetic purity, genetic diversity, seed production

\section{Introduction}

The Stylosanthes genus belongs to the family Leguminosae and subfamily Papilionoideae (Azani et al., 2017). Despite its high intraspecific and interspecific diversity, which has hindered its taxonomy (Mannetje, 1984; Maass and Sawkins, 2004; Stappen et al., 2002), 43 species of the genus Stylosanthes are recognized by the International Legume Database \& Information Service - ILDIS (Roskov et al., 2018). In Brazil, 31 species occur and 12 are endemic (Costa and Valls, 2015). However, agricultural use is limited to species S. guianensis (Aubl.) Sw. (diploid), Stylosanthes capitata Vogel (tetraploid) and Stylosanthes macrocephala M.B.Ferreira \& Sousa Costa (diploid) (Maass and Sawkins, 2004; Jank et al., 2011; Roskov et al., 2018).

In tropics, both species $S$. capitata and $S$. macrocephala grow well on acid, infertile soils in sub-humid savannah environments and exhibit tolerance to anthracnose (Grof et al., 1979; Miles and Lascano, 1997). Two cultivars were released, one in Colombia, S. capitata cv. Capica (CIAT 10280, CPAC 1618) and one in Brazil, S. macrocephala cv. Pioneiro (CIAT 1281 = BRA-003697); however, their adoption was constrained by weak agronomic performance (Miles and Lascano, 1997). Later, it was released in Brazil the cultivar named 'Estilosantes Campo Grande', formed by the physical mixture of anthracnose resistant accessions of $S$. macrocephala $(20 \%)$, with productive accessions of $S$. capitata (80 \%) (Embra- pa, 2000; Cook et al., 2005; Jank et al., 2011), and it is currently the most used commercial cultivar. However, because of the proximity of fields for seed production of $S$. capitata and $S$. macrocephala, and their morphological similarity, contamination of seed lots may occur, compromising seeds quality.

The combined use of dominant (as ISSR-Inter-Simple Sequence Repeat) and co-dominant (as SSR-Simple Sequence Repeat) molecular markers is an adequate strategy to certificate genetic purity and perform diversity studies on cultivars, both for scientific and commercial purposes. Thus, this study aimed to standardize a set of ISSR (Inter-Simple Sequence Repeat polymorphic DNA) and SSR (Simple Sequence Repeat polymorphic DNA) molecular markers to characterize the forage leguminous species Stylosanthes capitata Vogel and Stylosanthes macrocephala MB. Ferreira \& Sousa Costa that comprise cultivar 'Estilosantes Campo Grande' and evaluate genetic purity of commercial samples.

\section{Materials and Methods}

\section{Plant material}

Seeds of Stylosanthes capitata Vogel and Stylosanthes macrocephala MB. Ferreira \& Sousa Costa species used for this research were from two separated commercial seed lots, kindly provided by a Brazilian commercial seed company that uses these species to comprise the 
mixed commercial cultivar named "Estilosantes Campo Grande". Additionally, seeds of S. macrocephala cv. Pioneiro were used for fingerprint confirmation.

\section{Sampling of plant material}

Leaf samples from 80 adult individual plants of $S$. capitata were collected in the experiment conducted in the year 2015 under the "Temperature Free-Air Controlled Enhancement and free-air carbon dioxide enrichment" facility (Trop-T-FACE), installed in field conditions, in the municipality of Ribeirão Preto, São Paulo, Brazil (21 ${ }^{\circ} 10^{\prime} 30^{\prime \prime} \mathrm{S}, 47^{\circ} 48^{\prime} 38^{\prime \prime} \mathrm{W}$, altitude: $\left.546 \mathrm{~m}\right)$. For comparison, 80 samples of seeds of the commercial $S$. macrocephala and four samples of seeds of $S$. macrocephala cv. Pioneiro were germinated in vitro and their seedlings were sampled and stored at $-20{ }^{\circ} \mathrm{C}$ for further analysis. Also, foliar samples of 117 adult plants that showed a different morphology in the field, evidencing seed lot contamination, were stored at $-20{ }^{\circ} \mathrm{C}$ for further identification.

\section{DNA extraction and ISSR/SSR amplifications}

Total genomic DNA was extracted from the leaves of each plant sampled using the method described by Alzate-Marin et al. (2009), except for adult field plants contaminated with Stylosanthes sp. that were extracted using a commercial DNeasy Plant Mini Kit, since the previous protocol did not work for these samples.

\section{ISSR/SSR primers characterization}

Fifteen ISSR markers were tested for amplification of $S$. capitata and $S$. macrocephala according to the official list published by the University of British Columbia in Canada (Table 1). In addition, fifteen SSR primer pairs developed by Santos et al. (2009a; 2011) were tested and standardized for amplification of $S$. capitata and crosstransferability to $S$. macrocephala (Tables 1 and 2).

The SSR/ISSR PCR amplifications were similar to those reported in Moraes Filho et al. (2015). Since SSR amplifications with the annealing temperature previously described for these primers $\left(60^{\circ} \mathrm{C}\right)$ only worked in about $47 \%$ of our amplifications, we tested annealing temperatures between 55 and $62{ }^{\circ} \mathrm{C}$. The temperatures that were successful in the amplification of $S$. capitata were used to confirm cross-transferability of these markers in $S$. macrocephala (Santos et al., 2009a; 2011). The PCR products were denatured and separated in $8 \%$ denaturing polyacrylamide gels (SSR) and $8 \%$ non-denaturing polyacrylamide gels (ISSR) stained with silver nitrate (Sanguinetti et al., 1994). Alleles were sized by comparison to a standard 10-bp (SSR) and 50-bp (ISSR) DNA ladder.

Table 1 - Sequences of the molecular markers tested.

\begin{tabular}{|c|c|c|c|}
\hline \multicolumn{2}{|c|}{ ISSR } & \multicolumn{2}{|r|}{ SSR } \\
\hline Loci & Primer $^{\pi}$ & Loci & Primer Forward and Reverse \\
\hline UBC-1 & ACACACACACACACACT & SC 18-01 B3 & $\begin{array}{l}\text { 5' GGCTAAAGAACGGCTAATG 3' } \\
\text { 5' TCGAAAGATCCAAGAACAAA 3' }\end{array}$ \\
\hline UBC-2 & GAGAGAGAGAGAGAGAT & SC 18-01 C7Ba & $\begin{array}{l}\text { 5' CCGACCAAGGGGGATGTC 3' } \\
\text { 5' AAGTAGCAGCGGCGAGACC 3' }\end{array}$ \\
\hline UBC-13 & стстстстстстстстT & SC $18-01$ E11 & $\begin{array}{l}\text { 5' TGGAGACAACACCCTTATG 3' } \\
\text { 5' ATTCTATTACTCTTGCCTTTTCT 3' }\end{array}$ \\
\hline UBC-820 & GTGTGTGTGTGTGTGTC & SC $18-01 T$ F11A & $\begin{array}{l}\text { 5' CTTCTTTATCCCCACCTTTTT 3' } \\
\text { 5' AGCACACTCTTTGATGATGAG 3' }\end{array}$ \\
\hline UBC-834 & AGAGAGAGAGAGAGAGYT & SC 18-01 G4Ba & $\begin{array}{l}\text { 5' GCATAGCAGCATAGGTAGTAAA 3' } \\
\text { 5' ATGCCAGGGCTGATAGAAG 3' }\end{array}$ \\
\hline UBC-845 & сTСTCTCTCTCTCTCTRG & $S C 18-01 A 2 A^{b}$ & $\begin{array}{l}\text { 5' AGCAGCATAGGGAATAAAAT 3' } \\
\text { 5' CAAAGGCCTAATCAACTGTG 3' }\end{array}$ \\
\hline UBC-851 & GTGTGTGTGTGTGTGTYG & SC $18-01 B 4^{b}$ & $\begin{array}{l}\text { 5' GCTTAGGCCTTATCCAGAA 3' } \\
\text { 5' TTGAATTTGTTATTGCTACTACTT 3' }\end{array}$ \\
\hline UBC-858 & TGTGTGTGTGTGTGTGRT & SC $18-014^{b}$ & $\begin{array}{l}\text { 5' CGGCAACTGGGAAAAATAA 3' } \\
\text { 5' ATGGGTAATCACAAATCTTCAG 3' }\end{array}$ \\
\hline UBC-860 & TGTGTGTGTGTGTGTGRA & $\mathrm{SC} 18-02 \mathrm{E} 12^{\mathrm{b}}$ & $\begin{array}{l}\text { 5' AGGGGAAGGGCAAATGGT 3' } \\
\text { 5' GCATAGATGGCAAACAGAGACA 3' }\end{array}$ \\
\hline UBC-862 & AGCAGCAGCAGCAGCAGC & SC 18-01T F2b & $\begin{array}{l}\text { 5' CTGACCCCACCTAATGAGAAA 3' } \\
\text { 5' AGCAAAACAAAACAAACAACACTA 3' }\end{array}$ \\
\hline UBC-864 & ATGATGATGATGATGATG & SC 18-01T G9b & $\begin{array}{l}\text { 5' TCCAGCTAAAGGGCAACACA 3' } \\
\text { 5' CCACCGCACACCAGAGATT 3' }\end{array}$ \\
\hline UBC-866 & стсстсстсстсстсстс & SC $18-01 T$ G12A & $\begin{array}{l}\text { 5' ATGCTGATTTTTTGGCTCTTTT 3' } \\
\text { 5' CCCCTTTTGAACGGATTG 3' }\end{array}$ \\
\hline UBC-885 & BHBGAGAGAGAGAGAGA & SC $18-02 \mathrm{H}^{\mathrm{b}}$ & $\begin{array}{l}\text { 5' GTCATTGTCGTCGTCACC 3' } \\
\text { 5' ACCGCATAGCTGTCTTTATT 3' }\end{array}$ \\
\hline UBC-886 & VDVCTCTCTCTCTCTCT & SC $18-01 \mathrm{~T} \mathrm{H}^{\mathrm{b}}$ & $\begin{array}{l}\text { 5' GGTATATGGGAGTTCTTGTTCT 3' } \\
\text { 5' TTTGTTTGTTTTGCTTTTGTA 3' }\end{array}$ \\
\hline UBC-897 & CCGACTCGAGNNNNNNATGTGG & SC $18-01 H^{b}$ & $\begin{array}{l}\text { 5' GCATCATTTGCATTTGTTTT 3' } \\
\text { 5' CTATCACCTCTCCATACCTTATC 3' }\end{array}$ \\
\hline
\end{tabular}

${ }^{\pi} N=(A, G, C, T), R=(A, G), Y=(C, T), B=(C, G, T), D=(A, G, T), H=(A, C, T), V=(A, C, G)$. aSantos et al. (2009a); bSantos et al. (2011). 
Table 2 - SSR molecular markers developed for S. capitata (Santos et al., 2009a; 2011), standard annealing temperatures tested and transferability to $S$. macrocephala and S. macrocephala cv. Pioneiro. ${ }^{1}$ Indicate the temperature of successful DNA amplification.

\begin{tabular}{|c|c|c|c|c|c|c|c|c|c|c|c|c|c|}
\hline \multirow[b]{2}{*}{ Loci } & \multirow[b]{2}{*}{ Size range (bp) } & \multicolumn{8}{|c|}{ Tested temperatures for S. capitata $\left({ }^{\circ} \mathrm{C}\right)$} & \multicolumn{3}{|c|}{ Transferability to $S$. macrocephala } & \multirow{2}{*}{$\begin{array}{l}\text { S. Macrocephala } \\
\text { cv. Pioneiro }\end{array}$} \\
\hline & & 55 & 56 & 57 & 58 & 59 & 60 & 61 & 62 & Reported & This work ${ }^{£}$ & $\begin{array}{c}\text { Temperature } \\
\text { Tested/amplified }{ }^{1}\end{array}$ & \\
\hline SC $18-01 \mathrm{B3}^{\mathrm{a}}$ & $222-225$ & / & + & I & - & / & - & / & / & - & - & $56^{1}, 60$ & - \\
\hline$S C 18-01 C 7 B^{a}$ & $318-330$ & / & + & / & - & / & - & / & / & $t^{a}$ & + & $56^{1}, 58,60$ & + \\
\hline SC $18-01 \mathrm{E} 11^{\mathrm{a}}$ & $235-239$ & / & + & / & / & / & - & / & / & - & - & 56,60 & - \\
\hline SC $18-01 T$ F11A & $188-186$ & / & - & / & - & / & + & / & / & - & - & $56,58,60$ & - \\
\hline SC $18-01 \mathrm{G}_{4} \mathrm{~B}^{\mathrm{a}}$ & $250-255$ & - & + & l & / & l & - & / & / & $t^{a}$ & + & $56^{1}$ & + \\
\hline SC $18-01 A 2 A^{b}$ & $232-238$ & / & / & / & / & / & + & / & / & + & - & $60^{1}$ & - \\
\hline SC 18-01 B4 ${ }^{b}$ & $238-242$ & / & - & - & - & l & - & / & - & - & - & 55,56 & - \\
\hline SC $18-01 E 4^{b}$ & $300-310$ & / & / & / & / & / & + & / & / & + & + & $60^{1}$ & + \\
\hline SC 18-02 E12 & $270-305$ & / & - & / & $+^{*}$ & / & + & / & - & + & + & $58,60^{1}$ & + \\
\hline SC $18-01 T^{b} 2^{b}$ & $196-198$ & / & / & / & / & / & + & / & / & - & - & 60 & - \\
\hline SC $18-01 T^{6} 9^{b}$ & $242-245$ & / & l & l & l & l & + & / & / & + & $+^{\alpha}$ & $60^{1}$ & $+^{\alpha}$ \\
\hline SC 18-01T G12A & $240-260$ & / & - & / & - & + & - & / & - & - & - & 59 & - \\
\hline SC $18-02 \mathrm{H}^{\mathrm{b}}$ & $204-218$ & / & / & / & $+^{*}$ & $t^{*}$ & + & - & - & + & - & $58^{1}, 59^{1}, 60^{1}, 61,62$ & - \\
\hline $\mathrm{SC} 18-01 \mathrm{~T} \mathrm{H}^{\mathrm{b}}$ & $182-195$ & - & - & - & - & - & - & / & - & - & - & 55,57 & - \\
\hline SC $18-01 \mathrm{H}^{\mathrm{b}}$ & $192-196$ & + & / & / & / & / & - & / & / & - & - & 55,60 & - \\
\hline
\end{tabular}

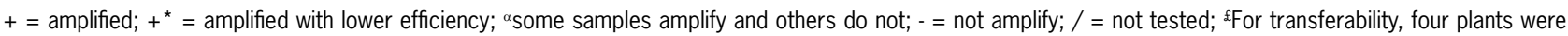
tested; aSantos et al. (2009a); 'bantos et al. (2011).

\section{Statistical Analyses}

The statistical analyses were similar to those fully described by Moraes Filho et al. (2015) for ISSR and SSR molecular markers. The GenAlex 6.5 software (Peakall and Smouse, 2012) was used to generate the genetic distance matrix according to Nei (1972) and calculate genetic diversity parameters and genetic differentiation between populations (AMOVA, $\mathrm{F}_{\mathrm{ST}}$ ) (Excoffier et al., 1992; Weir and Cockerham, 1984). The differences between means were performed with One-way ANOVA, followed by posthoc Tukey (significance level 0.05), using Excel tools and the PAST Sofware (Hammer et al., 2001). The software MEGA 5 (Tamura et al., 2011) was used to generate a dendrogram of genetic dissimilarity based on the UPGMA algorithm. The software Structure 2.0 (Pritchard et al., 2000) was used to investigate the genetic structure of samples from a cluster analysis based on models.

\section{Results}

\section{Standardization and selection of molecular markers}

Nine ISSR markers (UBC 1, 2, 834, 851, 860, 862, $864,885,886$ ) of 15 markers tested (Table 1) showed amplification products in $S$. capitata and $S$. macrocephala. Except for ISSR 1, the remaining eight markers were used to perform the genetic analysis of both species (Table 1 and Table 3).

From the fifteen SSR markers developed for S. capitata, annealing temperatures previously described $\left(60^{\circ}\right)$ for seven primers were confirmed and temperatures for the other six were standardized (Tables 1 and 2) (Santos et al., 2009a; Santos et al., 2011). We did not obtain amplification products with SSR SC18-01T H4 and SC18-01
Table 3 - Parameters of genetic diversity for $S$. capitata and $S$. macrocephala species with molecular markers ISSR. $A=$ number of alleles observed; $A e=$ effective number of alleles $\left[1 /\left(p^{\wedge} 2+q^{\wedge} 2\right)\right]$; $\mathrm{He}=$ Nei genetic diversity $\left[2^{\star} \mathrm{p}^{\star} \mathrm{q}\right] ; \mathrm{PL}=$ number of polymorphic loci; $\% \mathrm{P}=$ percentage of polymorphic loci; $\mathrm{SE}=$ standard error.

\begin{tabular}{|c|c|c|c|c|c|c|}
\hline & ISSR & $A$ & $\mathrm{Ae}$ & $\mathrm{He}$ & $\mathrm{PL}$ & $\% \mathrm{P}$ \\
\hline \multirow[t]{8}{*}{ S. capitata } & UBC-2 & 1.71 & 1.40 & 0.284 & 18.00 & 85.70 \\
\hline & UBC-834 & 2.00 & 1.39 & 0.246 & 09.00 & 100.00 \\
\hline & UBC-851 & 2.00 & 1.58 & 0.338 & 13.00 & 100.00 \\
\hline & UBC-860 & 1.90 & 1.61 & 0.344 & 10.00 & 90.00 \\
\hline & UBC-862 & 2.00 & 1.80 & 0.428 & 11.00 & 100.00 \\
\hline & UBC-864 & 1.50 & 1.47 & 0.283 & 12.00 & 75.00 \\
\hline & UBC-885 & 1.87 & 1.28 & 0.191 & 14.00 & 87.50 \\
\hline & UBC-886 & 1.95 & 1.45 & 0.275 & 19.00 & 95.00 \\
\hline Mean & & 1.84 & 1.49 & 0.292 & 13.25 & $91.65 \%$ \\
\hline SE & & 0.05 & 0.03 & 0.016 & - & 3.14 \\
\hline \multirow[t]{8}{*}{ S. macrocephala } & UBC-2 & 2.00 & 1.59 & 0.323 & 21.00 & 100.00 \\
\hline & UBC-834 & 1.77 & 1.43 & 0.256 & 08.00 & 89.00 \\
\hline & UBC-851 & 1.85 & 1.52 & 0.301 & 12.00 & 92.31 \\
\hline & UBC-860 & 2.00 & 1.54 & 0.312 & 10.00 & 100.00 \\
\hline & UBC-862 & 1.82 & 1.75 & 0.392 & 10.00 & 90.91 \\
\hline & UBC-864 & 1.63 & 1.48 & 0.270 & 12.00 & 75.00 \\
\hline & UBC-885 & 1.94 & 1.32 & 0.211 & 15.00 & 93.75 \\
\hline & UBC-886 & 1.90 & 1.40 & 0.245 & 18.00 & 90.00 \\
\hline Mean & & 1.87 & 1.50 & 0.285 & 13.25 & $91.36 \%$ \\
\hline SE & & 0.04 & 0.03 & 0.017 & - & 2.78 \\
\hline
\end{tabular}

B4 primers in our laboratory conditions after testing with seven and five temperatures, respectively (Table 2). Moreover, cross-transferability of five SSR markers to S. macrocephala was confirmed (Santos et al., 2009a; 2011), using related and new annealing temperatures (Table 2). 
Although SC18-01T G9 presents less reliable results in $S$. macrocephala, as it amplifies some samples and not others, this primer should be used with caution (Table 2). SSR molecular markers SC18-02 E12, SC18-01 E4, SC1801 G4B, and SC18-01 C7B, which amplified both species, were selected for the genetic characterization proposed.

\section{Genetic structure}

The cluster (Figures $1 \mathrm{~A}$ and $\mathrm{B}$ ) and the ancestry analysis (ISSR $\alpha=0.050 / \operatorname{SSR} \alpha=0.036$ ) (Figures $1 \mathrm{C}$ and D), with the two type of molecular markers, suggest that populations of both species are divided into two genetic groups, agreeing with the identification of individuals for each species. According to the STRUCTURE analysis, the "purest" sample was S. capitata, with $97 \%$ of its genetic composition assigned to a single genetic cluster. The $S$. macrocephala sample showed more considerable genetic mixture with $95 \%$ attributed to its principal ancestral group.

The joint analysis of both markers showed four contaminants in both groups analyzed, three $(4 \%)$ in the species $S$. macrocephala (M2, M11, and M12) and one $(1 \%)$ in the species $S$. capitata (C10.13) (Figures 1A, B, $\mathrm{C}$ and $\mathrm{D})$, which were removed for subsequent analyses. However, it is essential to highlight that this data was obtained after the removal of 117 contaminants in the field; therefore, it does not correspond the real S. capitata seed lot purity.

The analysis of molecular variance (AMOVA) showed that most genetic variability was found among species, and the ISSR analysis indicated a higher value $(\Phi S T=23.09)$ than the SSR markers $(\Phi S T=3.15)$ (Table 4). The $\mathrm{F}_{\mathrm{ST}}$ values showed differentiation $\left(\mathrm{SSR}-\mathrm{F}_{\mathrm{ST}}=\right.$ $0.366 \pm 0.061)$ and a small number of historical gene flow (SSR-Nm $=0.509 \pm 0.155$ ) between $S$. capitata and S. macrocephala species.

Table 4 - Molecular Analysis of Variance (AMOVA) $(p<0.05)$. Df $=$ Degrees of freedom; SS = Sum of Squares; EV = Estimated Variance; $\% \mathrm{~V}=$ Percentage of variance.

\begin{tabular}{|c|c|c|c|c|}
\hline & Df & SS & EV & $\% \mathrm{~V}$ \\
\hline \multicolumn{5}{|l|}{ ISSR Markers } \\
\hline Between Species Фst & 1 & 1812.23 & 23.09 & $67 \%$ \\
\hline Within Species $\Phi c t$ & 154 & 1754.01 & 11.39 & $33 \%$ \\
\hline Total & 155 & 3566.24 & 34.48 & $100 \%$ \\
\hline \multicolumn{5}{|l|}{ SSR Markers } \\
\hline Between Species Фst & 1 & 247.61 & 3.15 & $60 \%$ \\
\hline Within Species $\Phi c t$ & 154 & 321.30 & 2.09 & $40 \%$ \\
\hline Total & 155 & 568.91 & 5.24 & $100 \%$ \\
\hline
\end{tabular}
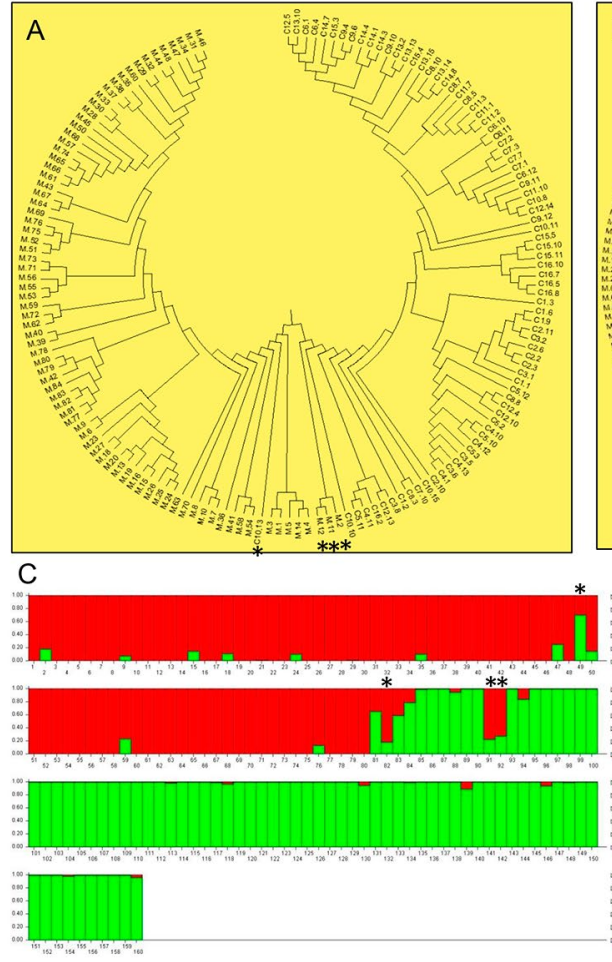

ISSR
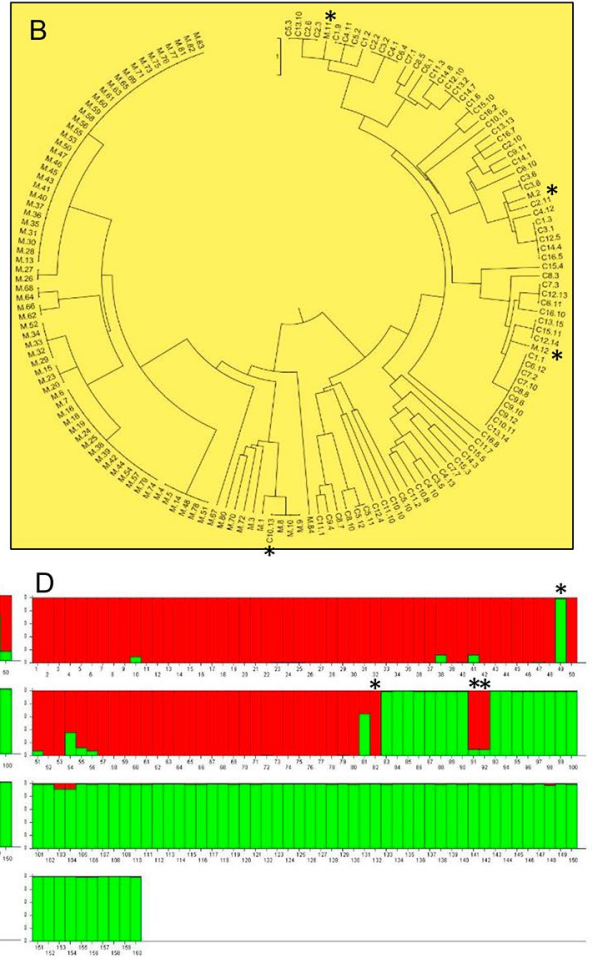

SSR

Figure 1 - Above (A, B): UPGMA dendrogram, demonstrating the genetic relationships among species Stylosanthes capitata and Stylosanthes macrocephala with ISSR/SSR markers. Below (C, D): Relationship of ancestry for the genetic cluster of individuals of the species $S$. capitata (red) and $S$. macrocephala (green), respectively. Both species samples were grouped into two major clusters. See the contaminant individuals $\left({ }^{*}\right) 49$ (C10.13) of S. capitata and individuals M2 (82), M11(91) and M12 (93) of S. macrocephala, respectively. 


\section{Diversity genetic analysis}

The eight selected ISSR primers generated 116 loci, with an average of 14.5 loci per primer, ranging from nine (UBC-834) to 21 (UBC-2). The average percentage of polymorphism of $S$. capitata $(\mathrm{M}=92 \%)$ was similar to $S$. macrocephala $(M=92 \%)$ (Table 3). No differences were observed for parameters $A$ (Number of different alleles), $\mathrm{Ae}$ (Number of effective alleles) and $\mathrm{He}$ (expected heterozygosity) between populations of both species $\left(H e_{\mathrm{Sc}}=0.292 \pm 0.016 ; \mathrm{He}_{\mathrm{Sm}}=0.285 \pm 0.017\right)$. Markers UBC 2, 864, 885 and 886 formed specific haplotypes of each species, including samples from $S$. macrocephala cv. Pioneiro, although the first two amplified higher quality fingerprints (Figures $2 \mathrm{~A}$ and $\mathrm{B}$ ).

The four SSR markers were polymorphic and generated 19 alleles $(A)$ for $S$. capitata with an average of $4.75 \pm 1.11$, ranging from two (SC18-01 G4B) to seven (SC18-02 E12) (Table 5). For S. macrocephala, ten alleles were amplified, a smaller number than for $S$. capitata, with an average of $2.50 \pm 0.87$, ranging from one (SC 18-01 G4B, monomorphic) to five (SC18-01 E4) (Table 5). $S$. capitata exhibited higher average values of $H e$ than $S$. macrocephala $\left(\mathrm{He}_{\mathrm{Sc}}=0.57 \pm 0.09 / \mathrm{He}_{\mathrm{Sm}}=0.16 \pm 0.14\right)$. Lower values of $F$ were observed in S. capitata (-0.06 \pm $0.41)$, while the highest values were found in $S$. mac- rocephala $(0.42 \pm 0.26)$, for which $F$ was positive and different from zero, indicating heterozygote deficiency, possibly due to the presence of monomorphic loci. In this sense, the lower diversity of $S$. macrocephala must be viewed with caution since the SSR markers used were transferred from $S$. capitata, which can present reduced polymorphism, as discussed by Guidugli et al. (2010). Nonetheless, Santos et al. (2012) reported similar interrelationships and results in $192 \mathrm{~S}$. capitata $(\mathrm{He}=0.50)$ and $134 \mathrm{~S}$. macrocephala $(\mathrm{He}=0.36)$ accessions, considering that the SSR markers used for the analysis of S. macrocephala were developed for the species (Santos et al., 2009b). Therefore, our diversity data are consistent with data previously published (Santos et al., 2009a; $2009 b ; 2012)$. According to the repeatability and quality, SC18-01 G4B is the most reliable SSR species-specific marker, amplifying simultaneously monomorphic alleles of different sizes by both species (Figure 2C).

\section{DNA analysis of contaminant plants in the field}

The fingerprint analysis of molecular markers ISSR UBC-864 and SSR SC18-01 G4B showed that contaminant plants discarded in the field belong to species S. macrocephala (Figures $2 \mathrm{~B}$ and $\mathrm{C}$ ), endorsing contamination of $S$. capitata commercial seeds used in the ex-

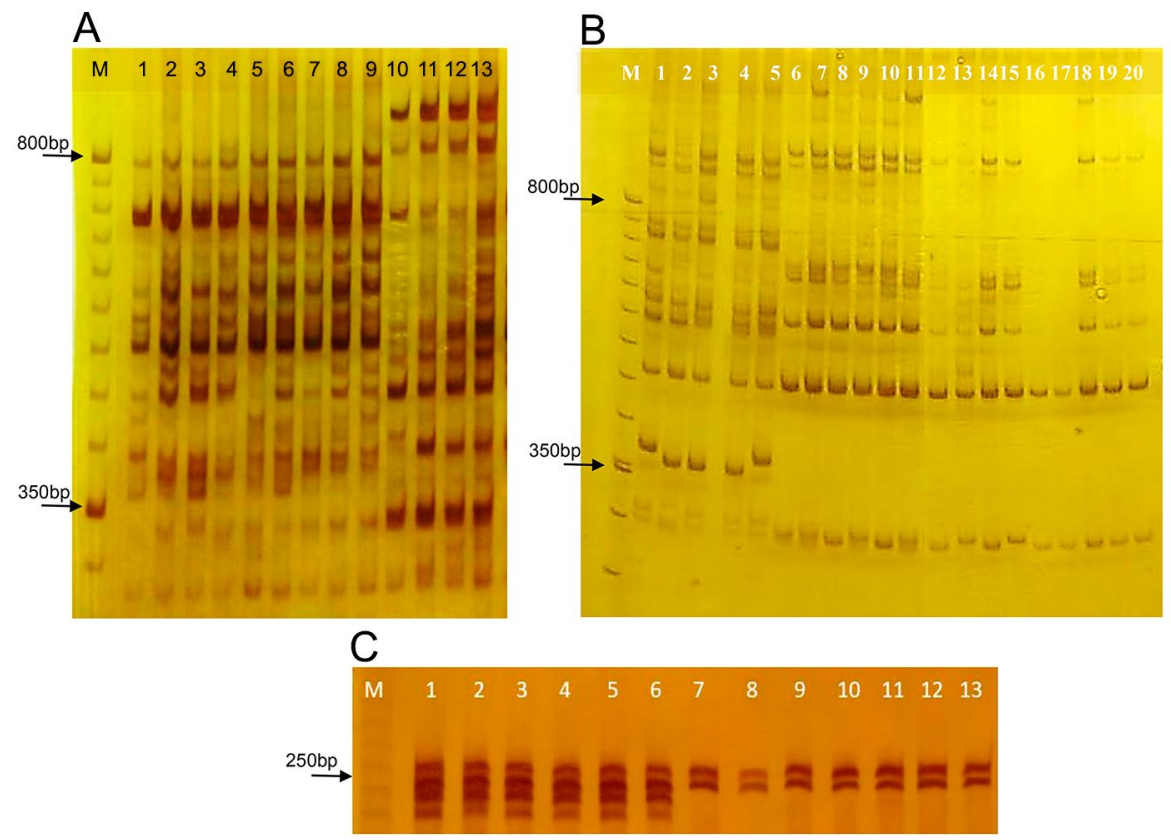

Figure 2 - Diagnostic fingerprints of Stylosanthes capitata and Stylosanthes macrocephala species generated by the amplification of ISSR markers UBC-2 (A) and UBC-864 (B), and SSR SC18-01 G4B (C) in polyacrylamide gel 8 \% non-denaturing (ISSR) and denaturing (SSR). A) Channels 1-4, 5-9 and 10-13 correspond to DNA amplification of the control samples of $S$. macrocephala, S. macrocephala cv. Pioneiro and S. capitata, respectively. B) Channels 1-5, 6-11 and 12-20 correspond to DNA amplification of the control samples of $S$. capitata, S. macrocephala, and some contaminant individuals observed in the field, respectively. C) Channels 1-6, 7-9, $10-11$ and 12-13 correspond to DNA amplification of control samples of $S$. capitata, S. macrocephala, two contaminant individuals observed in the field and $S$. macrocephala cv. Pioneiro, respectively. $\mathrm{M}$ is the molecular weight marker (50bp/ISSR, 10pb/SSR/Invitrogen). According to (B) and (C), contaminating plants in the field belong to $S$. macrocephala. 
periment. Some plants of $S$. macrocephala survived in the field and some differences were observed on their morphological characteristics regarding $S$. capitata when adults, such as smaller and narrower leaflets, hairiness, more branched and thin stems, more spaced trifoliate leaves, smaller flowers with brown nectar-guides (Figures 3A and B). However, according to Cook et al. (2005), brown nectar-guides are also observed in $S$. fruticosa, S. guianensis, S. hamata, S. humilis, S. scabra, S. seabrana and $S$. viscosa thus this morphological character must be used carefully as a phenotypic marker.

\section{Discussion}

In species of genus Stylosanthes, without a list of stable descriptors available for morphological characterization (Maass and Sawkins, 2004), molecular markers such as RAPDs, RFLPs, AFLPs, ITS, SSRs, SRAPs, and ISSRs can improve knowledge about germplasm and accesses deposited in collections, aiming their use in breed- ing programs (Santos et al., 2009a; 2009b; 2012; Vieira et al., 1997; Liu et al., 1999; Sawkins et al., 2001; Vander Stappen et al., 2002; Huang et al., 2014; Nagaich and Chandra, 2009). The ISSR markers are advantageous because the same primer may produce, simultaneously, distinctive fingerprints of different species (Zietkiewicz et al., 1994; Godwin et al., 1997; Sepúlveda-Nieto et al., 2017), as observed in Stylosanthes hamata (Nagaich and Chandra, 2009) and in this work. This type of molecular markers can be used efficiently for identification of genotypes, protection of intellectual property rights, and genetic purity analyses (Zietkiewicz et al., 1994; Rakoczy-Trojanowska and Bolibok, 2004; Kumar and Sharma, 2011). This economic strategy allows to confirm the identification of samples, avoiding wasting time with poorly classified materials that may falsely increase levels of genetic diversity within species, as observed by Santos et al. (2012) in studies with Germplasm Bank accessions of $S$. capitata. However, for microevolutionary purposes, microsatellite markers stand out as the most suitable for

Table 5 - Genetic diversity across $S$. capitata and $S$. macrocephala samples analyzed using simple sequence repeat (SSR) markers. $N=$ Number of individuals, $A=$ Number of alleles; $A e=$ Effective number of alleles; $H_{0}=$ Observed heterozygosity; $H e=$ Expected heterozygosity; $F=$ Fixation index; $\mathrm{Cl}-\mathrm{F}=$ Jackknife confidence intervals for the fixation index; $\mathrm{N}, \mathrm{A}, \mathrm{Ae}, \mathrm{Ho}, \mathrm{He}$ and $\mathrm{F}$ are reported as means (SE $=$ standard error).

\begin{tabular}{|c|c|c|c|c|c|c|c|c|}
\hline Species & Loci & $\mathrm{N}$ & A & $A e$ & Ho & $\mathrm{He}$ & $F$ & $\mathrm{Cl}-\mathrm{F}$ \\
\hline \multirow[t]{4}{*}{ S. capitata } & SC18-02 E12 & 77 & 7.00 & 4.14 & 0.21 & 0.76 & 0.73 & \\
\hline & SC18-01 E4 & 74 & 4.00 & 1.59 & 0.18 & 0.37 & 0.52 & \\
\hline & SC18-01 G4B & 79 & 2.00 & 2.00 & 1.00 & 0.50 & -1.00 & \\
\hline & SC18-01 C7B & 78 & 6.00 & 2.93 & 0.99 & 0.66 & -0.50 & \\
\hline Mean & & 77.00 & 4.75 & 2.66 & 0.59 & $0.57^{\star}$ & -0.06 & $-0.26-0.08$ \\
\hline SE & & 1.08 & 1.11 & 0.57 & 0.23 & 0.09 & 0.41 & - \\
\hline \multirow[t]{4}{*}{ S. macrocephala } & SC18-02 E12 & 76 & 2.00 & 1.01 & 0.01 & 0.013 & -0.01 & \\
\hline & SC18-01 E4 & 66 & 5.00 & 2.38 & 0.18 & 0.579 & 0.69 & \\
\hline & SC18-01 G4B & 76 & 1.00 & 1.00 & 0.00 & 0.000 & 1.00 & \\
\hline & SC18-01 C7B & 69 & 2.00 & 1.03 & 0.03 & 0.029 & -0.02 & \\
\hline Mean & & 71.75 & 2.50 & 1.36 & 0.06 & $0.16^{*}$ & 0.42 & $0.22-0.56$ \\
\hline SE & & 2.53 & 0.87 & 0.34 & 0.04 & 0.14 & 0.26 & - \\
\hline
\end{tabular}

${ }^{*} p \leq 0.05$.
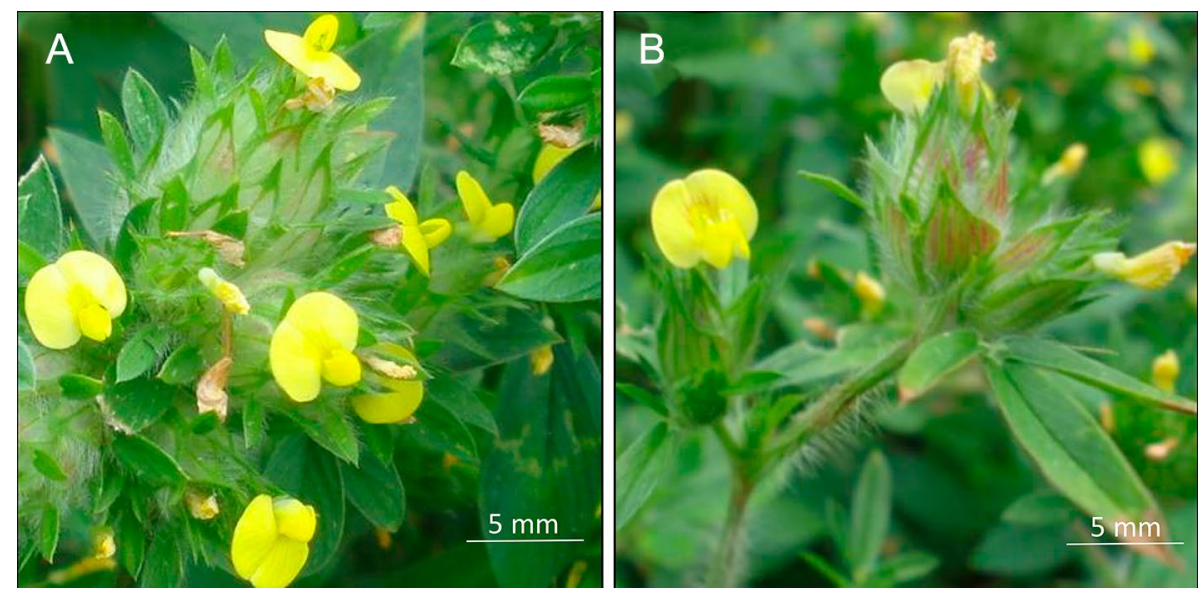

Figure 3 - Leaves, flowers and inflorescences of adult plants of the species Stylosanthes capitata (A) and Stylosanthes macrocephala (B) observed in the Trop-T-FACE experiment. 
crossing systems, gene flow and paternity studies, for their codominance of the alleles, easy detection via PCR, and high allelic diversity (Oliveira et al., 2006; Avise, 2004; Vieira et al., 2016). The synteny among related species allows SSR cross-transferability, and that the success depends on the phylogenetic distance (Zhu et al., 2005; Vieira et al., 2016).

In this work, we characterized the first time eight ISSR markers that can be used simultaneously in the genetic study of $S$. capitata and $S$. macrocephala, four of them amplifying fingerprints characteristics that can aid in characterization and identification of germplasm. Similarly, we finely characterized 15 previously developed SSR markers, with a gradient of annealing temperatures (Table 2) and verified their cross-transferability to S. macrocephala and S. macrocephala cv. Pioneiro. Also, for the first time, heterologous SSR markers SSR SC1802 E12, SC18-01 E4, SC18-01 G4B, SC18-01 C7B (Santos et al., 2009a; 2011) were genetically characterized in S. macrocephala (Table 5) and primer SC18-01 G4B was identified as the most reliable species-specific marker, amplifying simultaneously monomorphic alleles of different sizes in each species sample and identifying directly contaminant samples. Although $S$. macrocephala was a possible diploid ancestor of $S$. capitata (Maass and Sawkins, 2004), both species display a clear separation, as shown by the cluster, ancestry and genetic structure analyses (AMOVA and $\mathrm{F}_{\mathrm{ST}}$ ). Regarding diversity, the analysis with SSR markers shows higher values for $S$. capitata. In general, the two sets of molecular markers grouped samples of both species similarly and highlighted their genetic similarities and differences and the contamination cases in the samples.

The species-specific bands ISSR/SSR identified between both species are useful for the analysis of genetic purity, mainly because the mixture of both species comprise the cultivar "Estilosantes Campo-grande", currently the most important Brazilian forage legume. As the Stylosanthes genus has considerable agronomic, agroforestry and silvopastoral importance, both as a protein source and for soil conservation, accurate identification of this species is essential for further improvement of cultivars and transference of desirable features from wild species to domesticated ones (Gillies and Abbott, 1998; Cameron and Chakraborty, 2004). The integration of knowledge of diversity patterns, geographic information (Costa and Shultze-Kraft, 1990; Barros et al., 2005; Maass and Sawkins, 2004) and physiology (Martinez et al., 2014) allows understanding suitable ecological conditions for conservation of this species in nature as well as its most appropriate use, aiming at genetic improvement to reduce impacts of climate change in the future.

\section{Acknowledgements}

This work was financed by Fundação de Amparo à Pesquisa do Estado de São Paulo (FAPESP) Thematic Project (Grant 2008/58075-8), and Conselho Nacional de Desenvolvimento Científico e Tecnológico (CNPq) (Grant 446357/2015-4) to C.A.M., and FAPESP (Grant 2015/23930-9) to A.L.A.M. We also acknowledge the support of Coordenação de Aperfeiçoamento de Pessoal de Nivel Superior-Programa de Excelência Acadêmica (CAPES-PROEX) grants. C.C.S. was supported by IC (2014/24817-9) and TTIII FAPESP (2016/21182-8), fellowships, respectively. F.B.A. was supported by a TTIII FAPESP fellowship (2013/18633). L.G.S. and R.M.M.F. were supported by an MSc and the Programa Nacional de Pós Doutorado (PNPD) Fellowship from CAPES, respectively. P.M.S.R. was supported by DSc CNPq fellowship (140144/2016-1). A.L.A.M (PDS 150737/2014-9) and C.A.M. were supported by fellow's research from CNPq. The authors thank the help of Dra. Marcela Corbo Guidugli. The authors thank the commercial company seeds that gave us the seeds of $S$. capitata and $S$. macrocephala and Dr. Allan K.B. Ramos of Embrapa Cerrados for providing the seeds of $S$. macrocephala cv. Pioneiro.

\section{Authors' Contributions}

Conceptualization: Alzate-Marin, A.L.; Martinez, C.A. Data acquisition: Costa-Silva, C.; Rivas, P.M.S.; Santos, L.G.; Bonifacio-Anacleto, F. Data analysis: Moraes, R.M.; Costa-Silva, C.; Rivas, P.M.S.; Santos, L.G.; Bonifacio-Anacleto, F. Design of Methodology: Alzate-Marin, A.L. Writing and editing: Alzate-Marin, A.L.; Costa-Silva, C.; Rivas, P.M.S.; Moraes, R.M.; Martinez, C.A.

\section{References}

Alzate-Marin, A.L.; Guidugli, M.; Soriani, H.H.; Martinez, C.A.H.; Mestriner, M.A. 2009. An efficient and rapid DNA minipreparation procedure suitable for PCR/SSR and RAPD analyses in tropical forest tree species. Brazilian Archives of Biology and Technology 52: 1217-1224.

Avise, J.C. 2004. Molecular Markers: Natural History and Evolution. Sinauer, Sunderland, MA, USA.

Azani, N.; Babineau, M.; Bailey C.D.; Banks, H.; Barbosa, A.R.; Pinto, R.B. 2017. A new subfamily classification of the Leguminosae based on a taxonomically comprehensive phylogeny. Taxon 66: 44-77.

Barros, A.M.; Faleiro, F.G.; Karia, C.T.; Shiratsuchi, L.S.; Andrade, R.P.; Lopes, G.K.B. 2005. Genetic and ecological variability of Stylosanthes macrocephala determined by RAPD markers and GIS. Pesquisa Agropecuária Brasileira 40: 899-909 (in Portuguese, with abstract in English).

Cameron D.F.; Chakraborty, S. 2004. Forage potential of Stylosanthes in different production systems. p. 27-38. In: Chakraborty, S., ed. High-yielding anthracnose-resistant Stylosanthes for agricultural systems. CSIRO. Camberra, Australia.

Cook, B.G.; Pengelly, B.C.; Brown, S.D.; Donnelly, J.L.; Eagles, D.A.; Franco, M.A.; Hanson, J.; Mullen, B.F.; Partridge, I.J.; Peters, M.; Schultze-Kraft, R. 2005. Tropical forages: an interactive selection tool; Stylosanthes capitata, Stylosanthes macrocephala). CSIRO, Camberra, Australia. Available at: http://www.tropicalforages. info [Accessed July 24, 2018] 
Costa, L.C.; Valls, J.F.M. 2015. Stylosanthes in List of Species of Flora of Brazil. Botanical Garden of Rio de Janeiro = Stylosanthes in Lista de Espécies da Flora do Brasil. Jardim Botânico do Rio de Janeiro. Available at: http://floradobrasil. jbrj.gov.br/jabot/floradobrasil/FB29854 [Accessed July 24, 2018] (in Portuguese).

Costa, N.M.S.; Shultze-Kraft, R. 1990. Biogeography of Stylosanthes Capitata Vog. and Stylosanthes Gulanensis Sw. VAR. Pauciflora. Pesquisa Agropecuária Brasileira 25: 15471554 (in Portuguese, with abstract in English).

Empresa Brasileira de Pesquisa Agropecuária [Embrapa]. 2000. Estilosantes Campo Grande: establishment, management and animal production $=$ Estilosantes Campo Grande: estabelecimento, manejo e produção animal. Embrapa Gado de Corte, Campo Grande, MS, Brazil. (Comunicado Técnico, 61). Available at: https://www.embrapa.br/busca-depublicacoes/-/publicacao/323701/estilosantes-campo-grandeestabelecimento-manejo-e-producao-animal [Accessed July 25, 2018] (in Portuguese).

Excoffier, L.; Smouse, P.E.; Quattro, J.M. 1992. Analysis of molecular variance inferred from metric distances among DNA haplotypes: application to human mitochondrial DNA restriction data. Genetics 131: 479-491.

Gillies, A.C.M.; Abbott, R.J. 1998. Evaluation of random amplified polymorphic DNA for species identification and phylogenetic analysis in Stylosanthes (Fabaceae). Plant Systematics and Evolution 211: 201-216.

Godwin, I.D.; Aitken, E.A.B.; Smith, L.W. 1997. Application of inter simple sequence repeats (ISSR) markers to plant genetics. Electrophoresis 18: 1524-1528.

Grof, B.; Schultze-Kraft, R.; Muller, F. 1979. Stylosanthes capitata Vog., some agronomic attributes, and resistance to anthracnose (Colletotrichum gloeosporioides Penz.). Tropical Grasslands 13: 28-37.

Guidugli, M.C.; Accoroni, K.A.; Mestriner, M.A.; Contel, E.P.; Martinez, C.A.; Alzate-Marin, A.L. 2010. Genetic characterization of 12 heterologous microsatellite markers for the giant tropical tree Cariniana legalis (Lecythidaceae). Genetics and Molecular Biology 33: 131-134.

Hammer, O.; Harper, D.A.T.; Ryan, P.D. 2001. PAST: Paleontological statistics software package for education and data analysis. Paleontolologia Electronica 4: 9. Available at: https://palaeo-electronica.org/2001_1/past/past.pdf [Accessed July 12, 2018]

Huang, C.Q.; Liu, G.D.; Bai, C.J.; Wang, W.Q.; Tang, J. 2014. Application of SRAP markers in the identification of Stylosanthes guianensis hybrids. Molecular Biology Reports 41: 5923-9.

Jank, L.; Valle, C.B.; Resende, R.M.S. 2011. Breeding tropical forages. Crop Breeding and Applied Biotechnology S1: 2734.

Kumar, V.; Sharma, S.N. 2011. Comparative potential of phenotypic, ISSR and SSR markers for characterization of sesame (Sesamum indicum L.) varieties from India. Journal of Crop Science and Biotechnology 14: 163-171.

Liu, C.J.; Musial, J.M.; Thomas, B.D. 1999. Genetic relationships among Stylosanthes species revealed by RFLP and STS analyses. Theoretical and Applied Genetics 99: 1179-1186.
Maass, B.L.; Sawkins, M. 2004. History, relationships and diversity among Stylosanthes species of commercial significance. p. 9-26. In: Chakraborty, S., ed. High-yielding anthracnose-resistant Stylosanthes for agricultural systems. CSIRO, Camberra, Australia.

Mannetje, L.T. 1984. Considerations on the taxonomy of the genus Stylosanthes. p. 1-23. In: Stace, H.M.; Edye, L.A., eds. The biology and agronomy of Stylosanthes, Academic Press, New York, NY, USA.

Martinez, C.A.; Bianconi, M.; Silva, L.; Approbato, A.; Lemos, M.; Santos, L.; Curtarelli, L.; Rodrigues, A.; Mello, T.; Manchon, F. 2014. Moderate warming increases PSII performance, antioxidant scavenging systems and biomass production in Stylosanthes capitata Vogel. Environmental and Experimental Botany 102: 58-67.

Miles, J.W.; Lascano, C.E. 1997. Status of Stylosanthes development in other countries. I. Stylosanthes development and utilisation in South America. Tropical Grasslands 31: 454-459.

Moraes Filho, R.M.; Bonifacio-Anacleto, F.; Alzate-Marin, A.L. 2015. Fragmentation effects and genetic diversity of the key semidecidual forest species Metrodorea nigra in southwestern Brazil. Genetics and Molecular Research 14: 3509-3524.

Nagaich, D.; Chandra, A. 2009. Assessment of genetic diversity and identification of informative molecular markers for germplasm characterization in Caribbean stylo (Stylosanthes hamata). Journal of Plant Biochemistry \& Biotechnology 18: 257-260.

Nei, M. 1972. Genetic distance between populations. The American Naturalist 106: 283-292.

Oliveira, A.F.; Pádua, J.G.; Zucchi, M.I.; Vencovsky, R.; Vieira, M.L.C. 2006. Origin, evolution and genome distribution of microsatellites. Genetics and Molecular Biology 29: 294-307.

Peakall, R.; Smouse, P.E. 2012. GenAlEx 6.5: genetic analysis in Excel. Population genetic software for teaching and research-an update. Bioinformatics 28: 2537-2539.

Pritchard, J.K.; Stephens, M.; Donnelly, P. 2000. Inference of population structure using multilocus genotype data. Genetics 155: 945-959.

Rakoczy-Trojanowska, M.; Bolibok, H. 2004. Characteristics and a comparison of three classes of microsatellite-based markers and their application in plants. Cellular and Molecular Biology Letters 9: 221-238.

Roskov, Y.; Zarucchi, J.; Novoselova, M.; Bisby, F. 2018. ILDIS World Database of Legumes (version 12, May 2014). In: Roskov, Y.; Abucay, L.; Orrell, T.; Nicolson, D. Species 2000 \& ITIS Catalogue of life. Naturalis, Leiden, The Netherlands. Available at: www.catalogueoflife.org/col [Accessed July 25, 2018]

Sanguinetti, C.J.; Dias, E.N.; Simpson, A.J.G. 1994. Rapid silver staining and recovery of PCR products separated on polyacrylamide gels. Biotechniques 17: 914-921.

Santos, M.O.; Sassaki, R.P.; Chiari, L.; Resende, R.M.S.; Souza, A.P. 2009a. Isolation and characterization of microsatellite loci in tropical forage Stylosanthes capitata Vogel. Molecular Ecology Resources 9: 192-194.

Santos, M.O.; Sassaki, R.P.; Ferreira, T.H.S.; Resende, R.M.S.; Chiari, L.; Karina, C.T.; Faleiro, F.G.; Jungmann, L.; Zucchi, M.I.; Souza, A.P. 2009b. Polymorphic microsatellite loci for Stylosanthes macrocephala Ferr. et Costa, a tropical forage legume. Conservation Genetic Resources 1: 481-485. 
Santos, M.O.; Resende, R.M.S.; Chiari, L.; Zucchi, M.I.; Souza, A.P. 2011. Mating systems in tropical forages: Stylosanthes capitata Vog. and Stylosanthes guianensis (Aubl.) Sw. Euphytica 178: 185-193.

Santos, M.O.; Toledo-Silva, G.; Sassaki, R.P.; Ferreira, T.H.; Resende, R.M.S.; Chiari, L.; Karia, C.T.; Carvalho, M.A.; Faleiro, F.G.; Zucchi, M.I.; Souza, A.P. 2012. Using genetic diversity information to establish core collections of Stylosanthes capitata and Stylosanthes macrocephala. Genetics and Molecular Biology 35: 847-861.

Sawkins, M.C.; Maass, B.L.; Pengelly, C.; Newburry, H.J.; FordLloyd, B.V.; Maxted, N.; Smith, R. 2001. Geographical patterns of genetic variation in two species of Stylosanthes Sw. using amplified fragment lenght polymorphism. Molecular Ecology: 1947-1958.

Sepúlveda-Nieto, M.D.P.; Bonifacio-Anacleto, F.; Figueiredo, C.F.; Moraes-Filho, R.M.; Alzate-Marin, A.L. 2017. Accessible morphological and genetic markers for identification of taioba and taro, two forgotten human foods. Horticulturae 3: 49.

Stappen, J.V.; Laet, J.; Gama-López, S.; van Campenhout, S.; Volckaert, G. 2002. Phylogenetic analysis of Stylosanthes (Fabaceae) based on the internal transcribed spacer region (ITS) of nuclear ribosomal DNA. Plant Systematics and Evolution 234: $27-51$
Tamura, K.; Peterson, D.; Peterson, N.; Stecher, G.; Nei, M.; Kumar, S. 2011. MEGA5. Molecular evolutionary genetics analysis using maximum likelihood, evolutionary distance, and maximum parsimony methods. Molecular Biology and Evolution 28: 2731-2739.

Vieira, M.L.C.; Fungaro, M.H.P.; Jubier, M.F.; Lejeune, B. 1997. Determination of taxonomic relationships among Brazilian taxa of Stylosanthes Sw., Leguminosae, using RAPD markers. Pesquisa Agropecuária Brasileira 32: 305-310.

Vieira, M.L.C.; Santini, L.; Diniz, A.L.; Munhoz, C.F. 2016. Microsatellite markers: what they mean and why they are so useful. Genetics and Molecular Biology 39: 312-328.

Weir, B.S.; Cockerham, C.C. 1984. Estimating F-statistics for the analysis of population-structure. Evolution 38: 1358- 1370.

Zhu, H.; Choi, H-K.; Cook, D.R.; Shoemaker, R.C. 2005. Bridging model and crop legumes through comparative genomics. Plant Physiology 137: 1189-1196.

Zietkiewicz, E.; Rafalski, A.; Labuda, D. 1994. Genome fingerprinting by simple sequence repeat (SSR)-anchored polymerase chain reaction amplification. Genomics 20: 176183. 